Fidei: Jurnal Teologi Sistematika dan Praktika, Vol. 3, No. 2, Des. 2020

\title{
Penciptaan dalam Sastra Hikmat Perjanjian Lama serta Implikasinya bagi Pemeliharaan Alam
}

\author{
Roy Charly H.P. Sipahutar \\ Institut Agama Kristen Negeri Tarutung, Indonesia \\ Email: roycharlygpp@gmail.com
}

Diterima: 22 Juli 2020

Direvisi: 24 November 2020

Disetujui: 17 Desember 2020

\begin{abstract}
Abstrak
Artikel ini adalah suatu upaya mencari makna ekoteologis dari teks penciptaan yang ada dalam Sastra Hikmat Perjanjian Lama. Subordinasi tema penciptaan dengan tema teologi lain dalam Perjanjian Lama membuatnya tidak dapat berbicara secara utuh. Demikian pula upaya yang dilakukan dalam menggali tema penciptaan biasanya hanya seputar teks dalam kitab Kejadian, hal tersebut menafikan bahwa ada bagian lain dalam Perjanjian Lama yang berbicara lantang tentang tema penciptaan ini. Oleh karena itu tulisan ini mencoba mengeksplorasi tema penciptaan dari bagian Sastra Hikmat Perjanjian Lama dengan menggunakan metode studi pustaka, meneliti sumber-sumber referensi dari penelitian yang berkaitan dengan teks terpilih dan mengimplementasikannya bagi tanggung jawab umat terhadap pemeliharaan alam. Hasil penelitian mengemukakan bahwa manusia dan alam sesungguhnya berhadapan satu dengan yang lain sebagai subyek dengan subyek. Disharmonisasi hubungan dengan alam adalah menentang tujuan penciptaan itu sendiri. Bersahabat dengan alam berguna bukan hanya bagi manusia, tetapi hal tersebut merupakan pujian terbaik bagi Sang Pencipta.
\end{abstract}

Kata-Kata Kunci: Sastra Hikmat; Pemeliharaan Alam; Penciptaan.

\section{Abstract}

This article is an attempt to find the ecoteological meaning of the creation text that is in Old Testament Wisdom Literature. Subordination of the theme of creation with other theological themes in the Old Testament made it unable to 
speak fully. Likewise the efforts made in exploring the theme of creation are usually only about the text in the book of Genesis, it denies that there are other parts of the Old Testament that speak loudly about this theme of creation. Therefore this paper tries to explore the theme of creation from the Old Testament Wisdom section by using the literature study method, examining reference sources of research related to selected texts and implementing them for the people's responsibility for preserving nature. The results of the study suggest that humans and nature actually face each other as subject to subject. Disharmonizing the relationship with nature is against the purpose of creation itself. Friendship with nature is useful not only for humans, but it is the best praise for the Creator.

Keywords: Creation; Nature Preservation; Wisdom Literature.

\section{Pendahuluan}

Sejak lama telah terjadi ketegangan di dalam teologi Perjanjian Lama (PL) tentang apakah umat Israel lebih dulu mengalami Allah sebagai Penebus atau sebagai Pencipta? ${ }^{1}$ Tetapi dalam beberapa dasawarsa terakhir muncul kritik keras terhadap subordinasi teologi penciptaan. Menurut Westermann, penciptaan justru memberi konteks untuk tindakan penebusan sehingga karya Allah di dalam penciptaan sama pentingnya dengan tindakan Allah di dalam sejarah. ${ }^{2}$ Ketika orang-orang Kristen membicarakan tentang Pencipta dan penciptaan serta alam semesta, sadar atau tidak hal itu muncul dari bagian pertama Pengakuan Iman Rasuli: “Aku percaya kepada Allah...Pencipta langit dan bumi”. Demikian juga bagian kedua dan ketiga juga dimulai dengan frase yang sama: "Aku percaya...". Ketiga bagian credo tersebut mengaku kepada salah satu dari ketiga oknum Trinitas beserta karya-Nya. Hal ini mengindikasikan bahwa hubungan Allah dengan manusia sebagai Pencipta memiliki tempat yang sama dengan Allah sebagai Penyelamat. Iman kepada Pencipta sejajar dengan

${ }^{1}$ Mis. von Rad yang menekankan penebusan. Gerhard von Rad, Old Testament Theology Vol 1: The Theology of Israel's Historical Traditions (Norwich: SCM Press Ltd, 1975), 136139. Begitu juga. pandangan Barth. Lihat Christoph Barth, Theologia Perjanjian Lama 1 (Jakarta: BPK Gunung Mulia, 2017).

${ }^{2}$ Clauss Westermann, Elements of Old Testament Theology (Atlanta: John Knox, 1982), 15-17; Zimmerli juga memertanyakan mengapa doktrin penciptaan selalu ditempatkan sebagai "lapisan kedua" dari iman Israel. Dia menyangkal hal tersebut, karena pengenalan Israel terhadap Yahweh juga dinyatakan dengan karya penciptaan-Nya sebagaimana tradisi yang telah dimiliki oleh bangsa-bangsa sekitar. W. Zimmerli, Old Testament Theology in Outline (Atlanta: John Knox, 1978), 158. 
iman kepada Sang Penyelamat. ${ }^{3}$ Childs juga memertanyakan subordinasi tema penciptaan ini lantas mengusulkan untuk jangan mendekati kedua tema ini dari sudut subordinasi, tapi berinteraksi secara korelatif. ${ }^{4}$ Penciptaan dan penebusan adalah dua karya dari Allah yang bertindak dalam iman dan sejarah.

Demikian pula, referensi utama yang jamak dipergunakan sewaktu membicarakan tema penciptaan adalah kitab Kejadian (khususnya pasal 1 dan 2). ${ }^{5}$ Ini menggiring paradigma seolah tidak ada tema penciptaan di bagian lain PL. Penyebabnya bermacam, kurangnya penelitian kritis terhadap tema penciptaan atau bisa saja disebabkan pengaruh pandangan tradisional yang belum "menyandingkan" bagian lain PL sebagaimana Pentateukh. ${ }^{6}$ Padahal pertanyaan bagaimana bumi ini terwujud tentu tidak dapat dijawab secara komprehensif dan dijelaskan dalam satu atau dua perikop saja. Pertanyaan tentang arti dari kehidupan manusia tentu berbeda dengan arti dari dunia ini dan makhluk-makhluk hidup lain yang ada di dalamnya. Konsep dari keseluruhan hidup manusia dan dunia ini pada awalnya tentu sekali muncul dengan membicarakan tentang penciptaan. ${ }^{7}$

Dalam PL tidak hanya terdapat satu atau dua cerita yang bertemakan penciptaan, bukan hanya pada kitab permulaan tetapi di banyak bagian lain.

\footnotetext{
${ }^{3}$ Walaupun memang tidak ada formulasi langsung seperti “Aku percaya kepada Allah Pencipta langit dan bumi..." dalam PL atau mengikuti pemikiran von Rad tentang tidak ditemukannya iman Israel yang didasarkan pada Yahweh Sang Pencipta. Lihat Claus Westermann, "Biblical Reflection on Creator-Creation," in Creation in the Old Testament, ed. Benhard W. Anderson (Philadelphia: Fortress Press, 2012), 93.

${ }^{4}$ Brevard S. Childs, Old Testament Theology in Canonical Context (Philadelphia: Fortress Press, 1985), 32-35.

${ }^{5}$ Lihat misalnya tulisan Bernike Sihombing, "Studi Penciptaan Menurut Kitab Kejadian 1:1-31," Kurios 1, no. 1 (2018): 76-106; Juliman Harefa, "Makna Allah Pencipta Manusia Dan Problematika Arti Kata 'Kita' Di Dalam Kejadian 1:26-27," Epigraphe: Jurnal Teologi dan Pelayanan Kristiani 3, no. 2 (2019): 107-117.

${ }^{6}$ Bnd. Luther yang mengatakan bahwa sesungguhnya tulisan PL lainnya tidak memiliki kewibawaan sepantar dengan tradisi Musais. Emil G. Kraeling, The Old Testament Since the Reformation (New York: Schocken Books, 1969), 15-16. Dalam perspektif kanon, hal seperti ini tentunya harus dihindarkan.

${ }^{7}$ Westermann, Elements of Old Testament Theology. Misalnya di banyak bahasa dunia, kata yang menunjuk kepada "manusia" dan juga "bumi" muncul pada masa yang belakangan. Di banyak bahasa tersebut panggilan "manusia (man)" pada awalnya merupakan nama pribadi dan kemudian menunjuk kepada keseluruhan umat manusia. Demikian juga, ungkapan "bumi (world)" pada awalnya hanyalah menunjuk kepada bagian kecil dari suatu lingkungan. Tidak ada "manusia" ataupun "bumi" yang muncul begitu saja dalam lingkungan sejarah primitif. Mereka juga tidak dapat memahami konsep yang lain melalui cerita mereka sendiri, dan yang pasti setidaknya adalah mereka memiliki kesamaan bahwa dibalik ini semua ada oknum yang menciptakan.
} 
Sehingga dengan kepelbagaian cerita penciptaan dalam kitab suci dari segi pola dan waktu mengindikasikan bahwa umat Israel kuno ternyata juga memikirmikirkan atau merenungkan tentang penciptaan dalam cara-cara dan fase waktu yang berbeda. Tidak ada satu formulasi tradisi cerita yang mutlak dipegang menunjukkan adanya pergumulan yang terus-menerus di benak Israel kuno. ${ }^{8}$ Bukankah ini juga merupakan dasar yang kuat untuk menjadikan tema penciptaan menjadi salah satu pokok keimanan Israel yang sangat layak untuk diperbincangkan? Tulisan ini akan dimulai dengan menganalisa urgensi tema penciptaan dalam Sastra Hikmat kitab suci lalu mengeksplorasi beberapa perikop terpilih dari bagian Sastra Hikmat tersebut dalam perspektif ekoteologis untuk melihat kegunaannya bagi tanggung jawab umat Kristen terhadap pemeliharaan alam ciptaan. Beberapa argumentasi teolog yang relevan tentu juga dijadikan bahan pengayaan tulisan ini.

\section{Metode Penelitian}

Metode yang digunakan dalam penelitian ini adalah metode kualitatif yaitu metode penelitian kepustakaan (library research), terhadap berbagai sumber data seperti penelitian terdahulu dan referensi tafsiran kitab Amsal, Ayub dan Mazmur khususnya yang berkenaan dengan tema penciptaan yang terdapat dalam Sastra Hikmat Perjanjian Lama. Referensi ekoteologis yang telah ada juga dijadikan menjadi kacamata dasar dalam memahami teks-teks Sastra Hikmat tersebut dengan harapan untuk mendapatkan makna teologi yang nantinya dapat dijadikan dasar peimplementasian tanggung jawab umat Kristen terhadap pemeliharaan alam.

\section{Pembahasan dan Hasil}

\section{Tempat Tema Penciptaan dalam Sastra Hikmat}

"Kitab-kitab Hikmat PL dengan tegas selalu berjalan dalam cakrawala teologi penciptaan. Teologi di dalamnya adalah teologi penciptaan". ${ }^{9}$ Formulasi dua kalimat Zimmerli ini menjadi pegangan klasik para teolog akan pentingnya

${ }^{8}$ Firman Panjaitan and Hendro H. Siburian, "Allah Yang Kreatif Dan Dinamis Dalam Ayub 42: 7-17: Sebuah Perlawanan Terhadap Teologi Retribusi," Kurios: Jurnal Teologi dan Pendidikan Agama Kristen 6, no. 2 (2020): 240-254.

${ }^{9}$ W. Zimmerli, Ort Und Grenze Der Weisheit Im Rahmen Der Alttestamentlichen Theologie (Munich: Kaiser, 1963), 302; C. Hassel Bullock, An Introduction to the Old Testament Poetic Books (Chicago: Moody Press, 1988), 183-184. "Cerita-cerita penciptaan pada hakikatnya berada dalam kitab-kitab kebijaksanaan”. Celia-Deane Drummond, Teologi \& Ekologi (Jakarta: BPK Gunung Mulia, 2011), 26. 
tema penciptaan dalam sastra-sastra Hikmat. Tema penciptaan ini menjadi penting dalam bagian Sastra Hikmat karena bagian tersebut memiliki perhatian yang lebih akan suatu tatanan yang penuh keteraturan sekaligus jawaban atas fenomena yang terjadi dalam kehidupan manusia sejak zaman permulaan. Dunia ini merupakan suatu kesatuan (unitary). Pengetahuan tentang bumi ini dan pendidikan bagi manusia berjalan beriringan, demikian pula upaya untuk mengenali keteraturan dunia ini sebagai suatu kesatuan konteks sesuai dengan apa yang selalu dipergumulkan sastra hikmat tentang penciptaan. Tentu sekali hikmat tidak mungkin berpikir bahwa Allah menciptakan dunia ini dalam kondisi chaos, karena hikmat selalu berbicara tentang dunia yang penuh dengan keteraturan (bnd. Ams 8:22-31). ${ }^{10}$

Dalam bagian lain kitab Amsal juga ditemukan ayat-ayat yang bertemakan penciptaan. Beberapa amsal berbicara tentang Yahweh yang menciptakan orangorang miskin dan yang kaya dan juga para penindas $(17: 5 ; 14: 31 ; 22: 2 ; 29: 13)$. Ia menciptakan langit dan bumi dengan penuh hikmat (3:19-20; 8:22-31). Hikmat dikaitkan dengan Tuhan, Allah Israel, karena takut akan Tuhan adalah permulaan hikmat $(9: 10$; bnd. $15: 33 ; 1: 7)$. Dan hikmat ini pun merupakan sumber kehidupan (14:27; bnd. 13:14 dan 8:35). Memang, sesudah pembuangan, hikmat memainkan peranan yang besar. ${ }^{11}$ Dialah yang memampukan pemimpin memerintah, yang membina orang di jalan yang baik, yang memberi hidup dan pengertian kepada orang muda yang belum berpengalaman (bnd. 9:1-6). Hikmat juga sebagai pengantara ciptaan (Ams $8: 22-23,30,32,35) .^{12}$

Dalam kitab Ayub, tema penciptaan juga memiliki tempat dan fungsi yang sangat penting. Ayub 3 sebagai penghubung bagian prolog dengan keseluruhan puisi memulai tema penciptaan dalam Ayub. Di bagian lain dituliskan juga tentang penciptaan hewan-hewan (12:7-10), kejatuhan manusia $(14: 1,2,4)$, Allah yang menciptakan langit (26:13-14), dan hikmat manusia yang terbatas (pasal 28). Allah memerkenalkan diri-Nya sebagai pencipta dunia sebagai jawaban terhadap gugatan Ayub (38-42). Juga di berbagai tempat dalam Ayub terdapat ayat-ayat yang berisikan terminologi-terminologi yang biasa digunakan pada masa penciptaan. ${ }^{13}$ Fungsi dari tema penciptaan dalam Ayub adalah untuk

\footnotetext{
${ }^{10}$ Christoph Barth, Theologia Perjanjian Lama 1.

${ }^{11}$ Ibid.

12 Risnawaty Sinulingga, Tafsiran Alkitab: Kitab Amsal 1-9 (Jakarta: BPK Gunung

${ }^{13}$ Henry Morris, Biblical Creationism (Michigan: Grand Rapids, 1993), 68.
} Mulia, 2015), 370. 
menegaskan keyakinan penyair dalam puisi-puisinya akan kesadaran yang sungguh terhadap keterlibatan Yang Ilahi atas penciptaan. Allah dalam kitab Ayub adalah manifestasi atas pandangan manusia terhadap penciptaan tersebut. Karena itu tidaklah mengherankan bila terdapat perbedaan yang sangat radikal dengan berbagai kitab PL khususnya tentang pengungkapan diri Allah. ${ }^{14}$

Fungsi yang lain tema penciptaan dalam Ayub adalah untuk menggambarkan proses penebusan Allah. ${ }^{15}$ Tokoh Ayub ditebus dari ketidakmengertiannya tentang hubungannya dengan Allah. Ayub dikembalikan lagi kepada kehidupannya semula sejauh proses itu mampu dicerna oleh akal manusia sebagai perwujudan kemahakuasaan Allah. Dia dibebaskan dari rasa ketidakpastian dan keragu-raguan akibat penderitaan yang dialami, sehingga kembali menyadari kedudukannya di hadapan Pencipta. Penulis Ayub ingin menegaskan bahwa pengetahuan dan tradisi yang ada tidak selalu sejalan dengan pengalaman yang dialami oleh manusia, tradisi dan hikmat yang telah ada sering sekali benar tetapi tidak selalu benar. Mengungkapkan segala sesuatu sebagai hukuman juga tidak tepat. Sehingga memunculkan pertanyaan dari manakah kemungkinan harus memulai kemengertian itu, jawabnya adalah dengan menelusuri penciptaan. Berangkat dari keawalan sehingga mengerti kenyataan hidup yang dialami saat ini. Keadaan akhir tokoh Ayub menyimpulkan bahwa tatanan penciptaan itu tetap ada dan berlangsung selama bumi ciptaan ini masih ada. ${ }^{16}$

Kitab Pengkhotbah memulai sajiannya dengan sebuah observasi bahwa "keturunan yang satu pergi dan keturunan yang lain datang, tetapi bumi tetap ada" (1:4). Morris menyebutkan bahwa ini menyinggung riwayat silsilah yang terdapat pada Kej 5 dan 11, sementara Allah tidak pernah berhenti menciptakan karena bumi tetap ada selamanya. ${ }^{17}$ Jaminan ini lebih lanjut dijelaskan pada 3:14 yang menekankan tentang hikmat Allah yang menciptakan dunia dengan cara yang tidak tertandingi dan penciptaan tersebut tidak mungkin dilakukan oleh kekuatan-kekuatan lainnya, bahkan untuk merusaknya sekalipun karena "bumi

${ }^{14}$ Robert William Edward Forrest, The Creation Motif in the Book of Job (New York: The World Publishing Company, 1975), 17.

${ }^{15}$ Forrest, The Creation Motif in the Book of Job.

${ }^{16}$ Seperti apa yang dikatakan Combs tentang penciptaan: Yahweh bukan hanya sebatas yang layak dikagumi, karena Ia adalah Allah yang esa. Dia menjadi tempat pemujaan karena Dia adalah Sang Pencipta, yang mengalahkan segala kuasa kekacauan dan ilah-ilah yang ada, dan selalu menjaga tatanan-Nya dengan kreatif sampai akhirnya. Lihat A.E. Combs, The Creation Motifs in the Old Testament (Colombia: Colombia University Press, 1970), 201.

${ }^{17}$ Morris, Biblical Creationism. 
akan tetap ada". Tema yang utama dari Pengkhotbah adalah bahwa hikmat manusia dan segala usahanya adalah "kesia-siaan dan usaha menjaring angin" (1:14). Ayat-ayat ini mungkin sekali berhubungan dengan konsekuensi dari kejatuhan manusia ke dalam dosa (bnd. Kej 3:17-19), kutukan dosa tersebut membuat apa yang dilakukan manusia di bumi ini, menurut Pengkhotbah menjadi sebuah kesia-siaan $(2: 22,23)$. Prinsip rusaknya hidup manusia akibat keberdosaannya juga dicatat dalam 3:20 yang merupakan hasil refleksi dari firman Allah kepada Adam ketika masa penciptaan (Kej 3:19). Pada bagian akhir Pengkhotbah dimulai dengan wejangan hikmat kepada para muda; "Ingatlah akan Penciptamu pada masa mudamu..." (12:1). Bagi setiap orang yang hidup di bawah kutuk dosa dan kematian harus selalu mengingat bahwa segala sesuatu akan berakhir dan manusia akan kembali kepada debu seperti apa yang Allah katakan pada masa penciptaan (bnd. 12:7). ${ }^{18}$ Namun hikmat juga yang mengajarkan bahwa bagimanapun selama nafas masih diberikan oleh Sang Pencipta: “...takutlah akan Allah dan berpeganglah pada perintah-perintah-Nya" (12:13). Memang manusia tidak akan dapat mengetahui Allah dan sesuatu yang terjadi di dunia inipun merupakan sebuah misteri $(3: 14 ; 7: 14)$, namun melalui ciptaan-Nya manusia dapat melihat kebesaran Allah (7:13).

Tradisi hikmat yang berbicara tentang tema penciptaan juga terdapat pada Mazmur. ${ }^{19}$ Hermisson, juga Murphy, berkesimpulan setidaknya salah satu dari tulisan hasil karya penulis hikmat tersebut adalah yang terdapat dalam Mazmur 104. ${ }^{20}$ Mazmur ini adalah hasil dari pergumulan Israel terhadap teologi penciptaan pada periode-periode akhir setelah pembuangan, memiliki kemiripan pola dan pengajaran dengan Kej 1 dan istilah-istilah khusus yang juga sering dipakai dalam pengungkapan karya penciptaan oleh Allah di dalam sastra-sastra hikmat Israel yang dituangkan dalam bentuk pujian umat.

Penciptaan dalam sastra hikmat tentunya bukan hanya dimengerti sebagai sesuatu tentang permulaan segala sesuatu tetapi juga mengenai kelangsungan hidup di dalamnya. Keteraturan juga bukan sesuatu yang dipandang secara kaku

${ }^{18}$ E. Gerrit Singgih, Hidup Di Bawah Bayang-Bayang Maut: Sebuah Tafsir Kitab Pengkhotbah (Jakarta: BPK Gunung Mulia, 2011), 217.

${ }^{19} \mathrm{Hal}$ ini juga sesuai dengan apa yang dikatakan Eissfeldt tentang Kitab Mazmur: “...pemazmur menciptakan mazmur-mazmur yang bernuansa spritual dan berfungsi penting bagi kultus mereka ... beberapa dari mazmur tersebut berupa himne, memuji Allah dengan nilai hikmat yang sangat tinggi...". Otto Eissfeld, The Old Testament (Oxford: Basil Blackwell, 1966), 124.

${ }^{20}$ R. Murphy, A Consideration of the Classification Wisdom Psalms (Bonn: Congress Volume, 1963), 156. 
tak dapat berubah, namun lebih kepada kefleksibelan yang berlangsung secara terus-menerus. Bila Allah sering dikatakan dengan hikmat menciptakan segala sesuatu, namun hikmat itu sendiri selalu dibutuhkan sepanjang zaman, demikian juga pengajaran moral, untuk tetap menjaga keteraturan tersebut. ${ }^{21}$ Puisi-puisi yang ada juga tentunya mengandung unsur-unsur cerita purba, hanya tentunya yang menjadi tugas penulis Ibrani adalah membuat tulisan-tulisan tersebut memiliki kekhasan yang mencirikan keagungan Allah Israel, serta selanjutnya dapat menjawab pergumulan sosial dan keagamaan mereka ketika itu. ${ }^{22}$

\section{Amsal 8:22-31}

Kitab Amsal merupakan ajaran kebijaksanaan klasik dalam PL, dalam bentuk akhirnya merupakan kumpulan perkataan hikmat yang kaya dan kompleks yang berkisar dari nasihat akal sehat yang sangat praktis hingga pernyataan dan doktrin tentang rahasia hikmat sebagai inti kehidupan. Nasehat dan pengajaran hikmat dalam Amsal memiliki agenda bersama yaitu untuk berpikir, berbicara, dan hidup di dunia sesuai dengan kehendak Allah Sang Pencipta. Pengajaran hikmat yang berpusatkan kepada "takut akan Tuhan", rasa takut yang diimplementasikan dengan sikap hormat dan segan terhadap Tuhan dan harus tampak dalam kegiatan praksis sehari-harinya. ${ }^{23}$ Salah satu prinsip yang mendasari amsal-amsal hikmat ialah bahwa terdapat suatu hubungan mendasar antara tatanan alam (ciptaan) dengan tatanan kemasyarakatan (moral). Sehingga keteraturan ciptaan menjadi hal yang sangat penting bagi kelangsungan ketertiban moral. Para guru kebijaksanaan memang juga menekankan etika praktis. Seseorang dapat melihat apa yang perlu dilihat dalam kehidupan komunitas yang berkelanjutan jika ia dipenuhi hikmat. Tetapi karena tradisi hikmat tidak hanya pragmatis tetapi ingin melihat ke dasar realitas, refleksi tradisi tidak hanya praktis tetapi juga berusaha untuk menyelidiki realitas ciptaan Tuhan. Semakin berhikmat maka semakin ia berakhir dengan kekaguman, keajaiban dan pujian pada Sang Pencipta.

${ }^{21}$ Hans-Jurgen Hermisson, "Observations on the Creation Theology in Wisdom," in Creation in the Old Testament, ed. Bernhard W. Anderson (Philadelphia: Fortress Press, 1984), 122.

${ }^{22}$ S.L. Terrien, The Book of Job: Introduction and Exegetis (Nashville: Abingdon Press, 1954), 295-296.

${ }^{23}$ Ril Tampasigi and Peniel C.D. Maiaweng, "Tinjauan Teologis Tentang Takut Akan Tuhan Berdasarkan Kitab Amsal Dan Implementasinya Dalam Hidup Kekristenan,” Jurnal Jaffray 10, no. 1 (2012): 133. 
Dalam hal ini Amsal 8:22-31 dapat dianggap sebagai artikulasi teologis yang paling mengagumkan dan khas dalam pengajaran hikmat. Ayat-ayat ini umumnya dianggap sebagai penegasan teologis yang sangat penting. Hikmat bukan hanya kebijaksanaan pragmatis, tetapi hikmat adalah prinsip, kekuatan dan oknum penting dalam tindakan penciptaan. Di sini hikmat berbicara sebagai suara yang berperan kuat. Hikmat menegaskan bahwa ciptaan bukanlah terjadi begitu saja tetapi wujud dari keteraturan dan keindahan ciptaan Allah. "Pada mula pertama" sebelum permulaan bumi (ay.23) sebelum penciptaan, hikmat bersekutu dengan kuasa Allah. Hikmat ada di sana sebelum samudera raya ada, sebelum gunung dan bukit ada, sebelum bumi dan padang, sebelum langit dan kaki langit pada permukaan samudera (23-29). Bagi bangsa Israel kuno maupun bangsa-bangsa di sekitarnya, langit dianggap sebagai suatu bentangan yang solid (bnd. Kej 1:6) dan dilekatkan pada posisinya (27a). Bentangan yang solid ini terlihat bagaikan kubah ("cakrawala") yang berawal dan berakhir di samudera raya, dan pertemuan antara cakrawala dengan samudera raya dengan samudera raya seperti garis (27b). Pandangan yang menganggap bumi berbentuk datar adalah jamak dalam dunia kuno. ${ }^{24}$ Allah memersiapkan (bahakino, har. "ketika ia menyelesaikan") dan membuat langit (samayim) dalam posisi dan kedudukan yang teguh dan ia menentukan garis pembatas antara cakrawala (behuqo hug, har. "ketika ia menandai lengkungan") dengan samudera raya sehingga ada keteraturan di antara keduanya. ${ }^{25}$ Ketidakteraturan ataupun kekacacauan (chaos) di semesta bumi membutuhkan tatanan hikmat untuk merapikannnya menjadi suatu susunan yang teratur. ${ }^{26}$

Keteraturan yang menjadi tujuan penciptaan tampak pula dalam ayat-ayat selanjutnya: Ia menetapkan (baazoz, har. "meneguhkan") kediaman awan (sehaqim) dan mata air samudera raya (inot tehom), memisahkan dan memberi batas-batas laut, air dan daratan $(28,29)$. Dalam dunia kuno, laut (yam) ini merupakan simbol kekuatan yang dapat merusak kehidupan, sehingga dengan pengaturan yang dilakukan Allah adalah jaminan keberlangsungan kehidupan di bumi dari ancaman malapetaka yang dapat menghantamnya.

Hikmat adalah sekutu pertama Tuhan, asisten pertama, teman pertama dalam karya agung penciptaan. Dalam ayat 22-30 dideskripsikan perihal wibawa

${ }^{24}$ Asigor Parongna Sitanggang, "Pengaruh Kosmologi Bumi Datar Dalam Eskatologi Alkitab," BIA': Jurnal Teologi dan Pendidikan Kristen Kontekstual 3, no. 1 (2020): 94.

${ }^{25}$ Sinulingga, Tafsiran Alkitab: Kitab Amsal 1-9.

${ }^{26}$ Harls Evan Rianto Siahaan, "Hikmat Sebagai Implikasi Pendidikan Kristiani: Refleksi 1 Raja-Raja 3:1-15," DUNAMIS: Jurnal Penelitian Teologi dan Pendidikan Kristiani 1, no. 1 (2016): 17. 
hikmat melalui pernyataan tentang keberadaannya sebelum ciptaan lainnya. Hikmat berperan penting dalam pekerjaan Allah ketika menciptakan alam semesta demi kesejahteraan manusia. Hikmat yang telah menjadi milik-Nya sebelum alam semesta diciptakan tidak hanya hadir tetapi berperan penting dalam proses penciptaan itu, sehingga kekacauan yang ada diubah menjadi keteraturan. Hikmat juga berinteraksi dengan manusia untuk berjuang memelihara kesejahteraan tersebut. ${ }^{27}$ Hikmat menjadi pedoman, pola dam model bagi manusia dan seluruh ciptaan lainnya (ay. 31). Ia adalah tata tertib ilahi yang mendasari penciptaan. Dalam penciptaan Allah memberikan hikmat kepada manusia dalam hembusan nafas kehidupan dan yang tentunya menjadi pembimbing manusia untuk berjalan dalam pemeliharaan kehidupan dan ciptaan.

Tuhan dengan estetika yang cermat menciptakan dunia menjadi tempat dengan keteraturan yang indah. Dunia secara intrinsik dalam jalinan terdalamnya dirancang dan diperintahkan untuk menghasilkan kehidupan. Jika seseorang memiliki kehidupan dalam realitas ciptaan, ia tidak dapat melarikan diri atau keluar dari karakter yang menentukan ini baik secara estetika dan etika. Manusia sebagai co-creator Allah. Ia dihadirkan sebagai alat penerus keberlangsungan ciptaan. Manusia bertanggung jawab memelihara keteraturan ciptaan, keindahan dan keterjaminan keberlangsungan hidup di dalam dunia yang ditempatinya.

Pesan teologis yang seperti ini tentu saja jauh dari keselarasan dengan apa yang disarankan oleh para pemikir teologi proses. Keller, salah seorang teolog proses yang terkenal itu mengatakan bahwa Allah hanya memiliki kemampuan "memengaruhi" manusia, Ia sama sekali tidak berdaulat. ${ }^{28}$ Tentu hal ini sangat sulit untuk diterima dalam konteks Amsal 8, Allah dan hikmat adalah sentral dari penciptaan yang berdaulat penuh membentuk keteratuan. Manusia adalah mandataris-Nya yang berhikmat untuk memelihara keteraturan yang diciptakan Allah.

Ayub 38:1 - 40:5

Bila diperhatikan seksama, respon atau jawaban Allah pada perikop ini ditujukan bagi pernyataan Ayub yang terdapat pada pasal 31. Terdapat jarak

${ }^{27}$ Sinulingga, Tafsiran Alkitab: Kitab Amsal 1-9.

${ }^{28}$ James Keller, "Process Theism and Theodicies for Problems of Evil," in The Blackwell Companion to the Problem of Evil, ed. Daniel Howard-Snyder and Justin P. McBrayer (Oxford: Wiley Blackwell, 2013), 346-347. 
beberapa pasal karena adanya pidato Elihu di antara keduanya. Respon ilahi ini juga dibagi ke dalam dua pidato yang terpisah, bagian yang pertama (38-40:5) adalah bagian yang didahului dengan ungkapan pendahuluan yang sama: "Maka dari dalam badai Tuhan menjawab Ayub". Dan bagian kedua (40:6-41:25). Dan pada kesimpulan dari masing-masing ucapan ilahi tersebut adalah Ayub bertobat atas segala kebodohannya dalam ucapan-ucapan yang tidak ia mengerti (40:3-5). Pada bagian kesimpulan ini Ayub mengalami perubahan walaupun mungkin ia tidak mengerti terhadap jawaban Tuhan tersebut tetapi ia mengerti tentang kekerdilannya. $^{29}$

Tulisan ini hanya berfokus pada bagian yang pertama ucapan ilahi berisi gambaran tentang luas dan mahakuasanya kekuatan penciptaan yang dilakukan oleh Allah. ${ }^{30}$ Pertama, jawaban Allah sama sekali mengabaikan keluhan Ayub dan sekaligus menghindari pemberian tanggapan sumpah Ayub tentang ketidakberdosaannya. Kedua, meskipun Allah tidak menyebut adanya kesalahan yang dilakukan oleh Ayub, Ia juga tidak menunjukkan penyebab penderitaan Ayub. Sebaliknya seluruh pembicaraan itu dialihkan dari pertimbangan mengenai keadilan Allah ke pertimbangan mengenai hikmat-Nya. Hikmat Allah ditunjukkan dalam menyatakan diri-Nya sebagai Pencipta. Dia bertanggung jawab atas struktur penciptaan dunia dan kedaulatan-Nya dalam pemeliharaan.

Secara tersirat Tuhan menyatakan bahwa tatanan alam tidak ditetapkan dengan prinsip pembalasan sebagai dasar operasionalnya (38:26). Alam ini tidak secara otomatis melaksanakan prinsip pembalasan. ${ }^{31}$ Tema ini menjadi hal yang sangat penting bagi penghubung seluruh isi kitab Ayub dari permulaan hingga akhirnya. Dalam PL, penampakan Yahweh sering sekali dinampakkan dalam perwujudan badai (searah) atau berbicara di dalam badai (38:1; bnd. Mzm 18:717 dan Kel 19:17-20). ${ }^{32}$ Alex Luc mengatakan bahwa dengan kehadiran Allah melalui dan di dalam badai (searah) menunjukkan bahwa tidak ada satu pun kekuatan yang tidak dapat dikuasai-Nya, bahkan badai (searah) yang selalu dianggap dunia purba sebagai manifestasi kekuatan jahat yang tidak dapat

29 Allah membenarkan Ayub di hadapan sahabat-sahabatnya. Keadilan Allah dipertahankan, bukan dengan menetapkan penyebab "sah" dari penderitaan, tetapi dengan menunjukkan hikmat-Nya yang besar. David J.A. Clines, World Biblical Commentary Vo. 17 (Nashville: Thomas Nelson, 1989), lvii-lviii.

${ }^{30}$ Brevard S. Childs, Introduction to the Old Testament as Scripture (Philadelphia: Fortress Press, 1980), 39.

${ }^{31}$ John E. Hartley, The Book of Job (Michigan: Grand Rapids, 1988), 15.

32 J.H.Eaton, Job (London: T and T Clark, 1992), 25. 
dikendalikan oleh manusia dan kekuatan-kekuatan lainnya, segalanya di bawah kendali Tuhan. ${ }^{33}$

Allah bertanya kepada Ayub mengenai keindahan ciptaan-Nya. Hal itu memerlihatkan kemahakuasaan dan kebijaksanaan Allah. Apakah Ayub mengetahui hal tersebut? Dapatkah Ayub melakukan salah satunya? Ayub diajak untuk merenungkan dan mengalami lagi tentang alam semesta semenjak permulaan. Dalam dunia purba, bumi berbentuk flat datar yang ditopang oleh pilar-pilar. Langit adalah sebuah kubah yang padat di mana memiliki ruang bagi kehidupan manusia dan binatang-binatang yang menghuni bagian tengah di antara air tanah dan hujan. ${ }^{34}$ Pertama, pendirian bumi seolah-olah sebuah rumah yang dibangun dengan perincian arsitektur. Sidang surgawi (bene elohim, anakanak Allah) bergembira, di manakah Ayub ketika itu? (38:4-7). Pengetahuan Ayub nyatanya begitu terbatas tentang sesuatu yang bersifat vertikal. Ayub digugat dengan pengetahuan (daat) yang ada padanya. Bagaimana Ayub mengerti tentang penciptaan sedangkan ia tidak hadir pada masa bumi diciptakan? Bagaimana ia mengerti tentang pengaturan alam semesta? ${ }^{35}$ Dia tidak dapat mengerti tentang dimensi yang lain apa yang menopang dan siapa mendirikan pilar-pilar yang dipakai untuk menopang bumi. ${ }^{36} \mathrm{Di}$ sini Tuhan dilukiskan begitu transenden yang merancang segala sesuatunya tanpa bantuan siapa pun di dalam penciptaan dan tak tertandingi kebijaksanaan-Nya. ${ }^{37}$

Allah mengendalikan lautan (38:8-11), tidak ada petunjuk adanya perang melawan binatang buas seperti halnya dengan mitos-mitos purba. Sebaliknya laut dilahirkan, diberi pakaian dan dihias dengan indahnya. Tuhan tidak membiarkan kekacauan (chaos) begitu saja tetapi menyeimbangkan keteganganketegangan yang disimbolkan oleh binatang-binatang buas tersebut. Kebijaksanaan-Nya melampaui segalanya. ${ }^{38}$ Lautan bahkan disebutkan "dilahirkan" (ke luar dari dalam rahim"), ungkapan ini merupakan ciri khusus dari puisi tentang laut zaman purba, gelombang merupakan kebanggaannya

${ }^{33}$ Alex Luc, "Storm and the Message of Job," Journal for Study of the Old Testament 1 (2000): 111.

${ }^{34}$ C.S. Rodd, The Book of Job (London: Epworth Press, 1990), 73-73.

${ }^{35}$ Norman C. Habel, The Earth Story in Wisdom Tradition (Sheffield: Sheffield Academi Press, 2001), 111.

${ }^{36}$ Rodd, The Book of Job.

37 Daniel Timmer, “God's Speeches and Job's Responses," The Chatolic Biblical Quarterly 7 (2009): 292.

${ }^{38}$ Michael B. Dick, "The Neo-Assyrian Royal Lion Hunt and Yahweh's Answer to Job," Journal Biblical Literature 125/2 (2006): 266; Marie-Claire Barth-Frommel, Ayub: Bergumul Dengan Penderitaan, Bergumul Dengan Allah (Jakarta: BPK Gunung Mulia, 2016), 136. 
(congkak, gaon) yang ditakuti manusia pada zaman tersebut tetapi Tuhan menyebutkan tak ada yang tak berasal dari-Nya, kecongkakan itu juga akan dihentikannya (ay.11). ${ }^{39}$ Dan bagaimana pagi (38:12-15) ketika embun memberi warna segalanya (14) dan menerangi perbuatan kegelapan para pendosa (15). Gambaran tentang fajar (hassahar) adalah sebuah perumpamaan yang sangat indah. Fajar digambarkan sebagai ujung selimut yang menutupi bumi dan mengibaskan bintang-bintang yang menentangnya. Ini gambaran tentang keadilan yang sejak penciptaan telah merupakan eksistensi dari diri Tuhan. ${ }^{40}$ Keadilan bagi semesta, bukan hanya kepada manusia tetapi damai sejahtera untuk seluruh alam di bumi. Kepongahan makhluk yang merasa memiliki semesta segera dihentikan, fajar pagi yang menyingsing adalah harapan setiap penghuni bumi untuk dapat bergandeng tangan menyambut bumi baru yang hijau dan ramah bagi semuanya. Antroposentrisme harus ditinggalkan, bumi diciptakan bukan hanya untuk kepentingan manusia. ${ }^{41}$

Laut tampak dengan pasangannya yang merusak yakni maut (38:16-18). Samudera (tehom) adalah kuasa yang telah ditaklukkan sewaktu penciptaan langit dan bumi dimulai karena kekacauan yang terjadi di alam samudera sering sekali dipersonifikasikan sebagai gambaran kekacauan umat manusia di bumi. Kata "sampai ke sumber laut" (ad-nivke-yam) tampaknya disadur dari cerita Kanaan tentang Dewa El'at, yang hidup dan berkuasa di bawah tanah kedalaman laut. ${ }^{42}$ Kedalaman laut adalah simbol dari kematian, tetapi Tuhan menguasai segala tempat sampai ke ujung-ujung bumi. Bumi dan alam sudah didamaikan melalui penciptaan, manusia adalah mandataris untuk memelihara kedamaian itu.

Kegelapan (ay.19, ofel) menunjuk kepada kekacaubalauan selayaknya keadaan pada waktu sebelum penciptaan. ${ }^{43}$ Kegelapan dan terang sering sekali dipercaya sebagai dua kekuatan yang saling berebut untuk menguasai kosmis. Bukankah sebenarnya Tuhan telah mengalahkan segala sesuatu kekacauan dan

${ }^{39}$ Hermisson, "Observations on the Creation Theology in Wisdom."

${ }^{40}$ Rodd, The Book of Job.

${ }^{41}$ Nalar antroposentrisme penyebab utama munculnya krisis ciptaan, egosentrisme. Sahat Martua Lumbantobing, "Alam Dan Manusia: Vis a Vis," Jurnal Teologi Anugerah 3, no. 2 (2012): 57.

${ }^{42}$ Norman C. Habel, The Book of Job (London: SCM Press Ltd, 1985), 540.

${ }^{43}$ Andrew Bruce Davidson, A Commentary, Grammatical and Exegetical, on the Book of Job (Edinburgh: Biblio Life, 2011), 44. 
memisahkan antara gelap dan terang (siang dan malam) pada awal mula penciptaan $?^{44}$ Tuhan menguasai terang dan kegelapan.

Sesudah menyinggung susunan permulaan dari kosmos, misteri dalam alam semesta disingkap terutama gejala cuaca (38:22-30). Mulanya ada salju, hujan es, dan angin (22-24), diikuti oleh hujan yang juga jatuh di hutan (26-27). Perhatian Allah adalah lebih luas daripada Ayub yang hanya berpusat pada kegiatan manusia (25-28). Penyelenggaraan yang dilakukan Allah berlangsung secara-terus menerus, tidak hanya kehidupan manusia yang menjadi pusat perhatian tetapi seluruh alam dan seisi bumi ini. ${ }^{45}$ Pandangan yang berpikiran bahwa bumi diciptakan untuk memuaskan kebutuhan manusia sudah harus ditinggalkan, semua aspek di bumi ini harus berjalan harmonis untuk kesejahteraan.

Bagi banyak orang dalam dunia kuno nasib manusia tertulis pada bintangbintang. Susunan langit dibicarakan (31-33), penyebutan "Mintakulburuj" (ay.32) tidak begitu jelas maksudnya. Ada beberapa tafsiran, mungkin ada hubungannya dengan tata bintang ("rasi bintang" mazzarot) Dapatkah Ayub mengendalikan mereka ini? Atau, dapatkah ia memberi hujan, menyelimuti diri dalam awan badai? (34-35) Tuhanlah yang menciptakan itu semua dalam kebijaksanaan. Di Babilonia, pensakralan bintang-bintang sangat menonjol. Segala benda di langit memengaruhi kehidupan manusia di bumi. Demikian pula di Mesir, dalam mitologinya disebutkan kosmos ini diciptakan oleh ilah sang matahari. Ilah sang matahari menciptakan dirinya sendiri, kemudian membentuk bayang-bayang atau ide-ide makhluk yang akan dijadikan, dia menghamili diri sendiri dan menghasilkan ilah-ilah lainnya, dalam tahap berikutnya ia menghancurkan naga kegelapan. ${ }^{46}$

Pembicaraan selanjutnya adalah mengenai dunia binatang (39:1-40:30). Lima pasang binatang buas disebutkan: singa dan gagak (39:1-3); kambing gunung dan rusa (39:4-7); keledai liar dan lembu hutan (39:8-15); burung unta dan kuda perang (39:16-28); burung elang dan rajawali (39:29-33). Disorotilah pengetahuan dan penyelenggaraan Allah. Tetapi di sini lebih daripada sekadar untuk dilihat. Deretan binatang ini pastilah dipilih tidak dengan sembarangan. Menurut penyelidikan mengenai dunia Timur Dekat kuno, banyak dari lambanglambang binatang tersebut memiliki makna yang negatif (iblis, chaos, kekacauan, kematian). Mereka mewakili sebuah dunia yang bertentangan

\footnotetext{
${ }^{44}$ Habel, The Book of Job.

${ }^{45}$ Rodd, The Book of Job.

${ }^{46}$ Th. C. Vriezen, Agama Israel Kuno (Jakarta: BPK Gunung Mulia, 2012), 38.
} 
dengan manusia. ${ }^{47}$ Semua itu telah tunduk di bawah keteraturan Allah. Seperti lembu hutan yang buas berubah menjadi segala macam lembu yang memungkinkan pekerjaan para petani berhasil baik (bnd. 39:13-14). ${ }^{48}$

Demikianlah, bahwa bagian yang pertama perkataan (jawaban) Tuhan ini menjawab tuduhan Ayub bahwa tidak ada rencana, pengarahan atau penyelenggaraan di dalam dunia. Pertama, Tuhan menunjukkan siapa yang bertanggung jawab atas semesta alam baik susunannya maupun perjalanannya secara teratur; dan ini semua tidak akan pernah menjadi kacau (chaos). Selanjutnya sebagai Tuan atas segalanya, Tuhan melindungi kehidupan dan budaya manusia dari kekacauan. Manusia harus mensyukurinya dan menjaga ciptaan Tuhan. Namun ini tidak berarti juga bahwa manusia terjebak demikian saja dalam "kurungan" kehendak Tuhan, seolah-olah ia robot seperti apa yang diusulkan dalam paham determinis. Feinberg, seorang teolog Calvinis menyebutkan bahwa tetap saja ada ruang yang luas bagi manusia ciptaan dalam kehendaknya untuk turut serta menentukan arah perjalanan dunia yang dalam hal ini keberlangsungan alam. ${ }^{49}$ Manusia tidak hanya menerima begitu saja namun bertindak aktif dalam tanggung jawab ekologis. ${ }^{50}$

\section{Mazmur 104}

Beberapa ahli menyebutkan bahwa Mzm 104 ini merupakan madah perorangan, ${ }^{51}$ walaupun ia anonim. Gambaran yang menyeluruh dari himne ini menurut Crusemann merupakan gabungan antara gaya pengaguman terhadap keagungan alam dan pujian langsung kepada Allah. ${ }^{52}$ Tentang latar belakang liturgisnya cukup banyak penafsir berpendapat bahwa mazmur ini dinyanyikan pada hari raya pengumpulan hasil pada akhir tahun agraris yang kemudian menjadi hari raya Pondok Daun. Kapan mazmur ini digubah? Untuk menjawab

${ }^{47}$ Dick, "The Neo-Assyrian Royal Lion Hunt and Yahweh's Answer to Job."

${ }^{48}$ Barth-Frommel, Ayub: Bergumul Dengan Penderitaan, Bergumul Dengan Allah.

49 John Feinberg, "God Ordains All Things," in Predestination and Free Will: Four Views of Divine Sovereignty and Human Freedom, ed. David Basinger and Randall Basinger (Downers Grove: Inter-Varsity Press, 2006), 25-26.

${ }^{50}$ Bahkan menurut hemat saya, dalam konteks PL, bergerak aktif melakukan kebaikan dan kebenaran adalah cara terbaik untuk memelihara kekudusan diri. Lihat selengkapnya dalam Roy Charly HP Sipahutar, "Revitalisasi Kekudusan Dalam Hidup Pelayan Kristen," Cultivation 476-482 (2018).

${ }^{51}$ Pandangan ini dikuatkan dengan melihat ayat 1, 33-34, 35. Lihat Sia Kok Sin et al., "Mengalami Allah Melalui Kitab Mazmur 1," Aletheia 18, no. April 2016 (2016): 112.

${ }^{52}$ Leslie C. Allen, Word Biblical Commentary Volume 21: Psalms 101-150 (Waco: Word Press, 1983), 28. 
pertanyaan ini kita perlu memertimbangkan beberapa hal: pertama, adanya persamaan antara ay.19-30 dengan suatu madah Mesir yang berasal dari abad 14 sM pada zaman pemerintahan Amenofis IV (Akhenaten) dan dipersembahkan kepada dewa Aten, dewa matahari. ${ }^{53}$ Walaupun untuk hal ini tidak sedikit sarjana yang meragukan, misalnya Walton yang menganggap bahwa kesejajaran keduanya tidak begitu kuat sehingga mazmur ini tidak dapat begitu saja dikatakan mengambil alih madah Mesir tersebut. ${ }^{54}$

Kedua, mazmur ini juga disebutkan memiliki banyak persamaan dengan pandangan dunia Timur Dekat kuno khususnya Kanaan tentang dewa badai (Hadad atau Baal). Himne Kanaan tersebut sejajar dengan Mzm 104 ini yang mengungkapkan keagungan penciptaan sebagai dasar pemujian kepada dewa. ${ }^{55}$ Menanggapi hipotesa ini Walton memberikan kesimpulan dengan pendekatan sosiologis-religi. Sebagaimana Bait Allah Salomo yang tentu saja memiliki kesamaan dengan kuil-kuil yang ada di sekitarnya, demikian pula mazmur pujian Israel dengan himne yang ada di sekitar mereka, sesuatu yang wajar dalam pergaulan internasional bangsa-bangsa. Namun hal tersebut tidak menafikan kekhasan dari mazmur Israel akan pengertian mereka terhadap Penciptanya. ${ }^{56}$

Yang ketiga, di lain pihak, unsur-unsur persamaan Mzm 104 ini dengan teks-teks lain dalam kitab suci juga tidak kecil seperti dengan cerita penciptaan Kej 1 dan kekaguman akan keagungan Allah dalam segala karya ciptaan-Nya sebagaimana juga dalam Ayub 3 dan 38. ${ }^{57}$ Tentunya ini membawa kepada analisa yang sederhana, bahwa mazmur ini telah lama ada dan berkembang dalam tradisi lisan dan sastra Israel namun kemudian digubah pada masa

${ }^{53}$ C.F. Keil and F.Delitzsch, Commentary on the Old Testament in Ten Volumes (Vol. VIII) (Michigan: Grand Rapids, n.d.), 126-127.

${ }^{54}$ Lebih lanjut Walton menyebutkan bahwa motif, analogi, dan unsur-unsur yang terdapat dalam Mzm 104 sesungguhnya tidak hanya dimiliki oleh madah tersebut, karena hampir ribuan madah Mesir bahkan di Timur Dekat kuno ketika itu juga berisikan hal yang sama. Lihat John H. Walton, Ancient Israelite Literature in Its Cultural Context: A Survey of Parallels Psalms (Michigan: Grand Rapids, 1989), 164; G.R. Driver, The Psalms in the Light of Babylonia Research (Michigan: Grand Rapids, 1990), 122.

${ }^{55}$ Walaupun demikian perbedaan mencolok juga tampak, bagaimana dalam Himne Kanaan tersebut tidak dinyatakan perbedaan antara matahari dan dewa, namun Mzm 104 mengisahkan bahwa matahari dan benda-benda penerang apapun adalah benda ciptaan Tuhan. Lihat Allen, Word Biblical Commentary Volume 21: Psalms 101-150.

${ }^{56}$ Walton, Ancient Israelite Literature in Its Cultural Context: A Survey of Parallels Psalms.

${ }^{57}$ Keil and F.Delitzsch, Commentary on the Old Testament in Ten Volumes (Vol. VIII). 
pembuangan bahkan mungkin sekali setelah pembuangan ketika Bait Allah dibangun kembali, untuk kepentingan pujian dalam ibadah Israel.

Mzm 104 dimulai dengan karya Ilahi tentang tindakan penciptaan yang dilakukan Allah (ay.1-4). Dia Raja yang pakaian-Nya adalah keagungan dan semarak (1c), terang adalah selimut-Nya (2a). Pernyataan ini termasuk khas mazmur menunjukkan keagungan Tuhan, sifat Allah yang Agung. Stott mengomentari bagian ini dengan mengatakan bahwa Allah adalah Tuhan yang mencipta seluruh alam dan dengan penciptaan Dia menyatakan diri-nya melalui alam ini juga. Seharusnya dalam keberadaan-Nya kita tidak mampu mengenalNya namun dengan ciptaan-Nya kita menjadi mengenal-nya. ${ }^{58}$ Kebesaran rajawi Tuhan tampak dalam kuasa-Nya sebagai pencipta langit (2b-3a) dan penguasa badai (3b-4). Dia membentangkan langit seperti tenda dan mendirikan istanaNya di atas air yang ada di atas langit (2b-3a). Awan, angin api dan nyala api di sini disebutkan bersama-sama untuk menyatakan kekuatan-kekuatan alam yang menyertai badai. Bukan Baal yang menguasai mereka, tetap Tuhan Sang Pencipta.

Lalu Allah yang meletakkan dasar bumi dan menetukan batas-batas samudera dengan menghadirkan gunung-gunung (5-9), bait ini menyanyikan kebesaran Tuhan sebagai pencipta bumi. Tuhan menciptakan bumi dengan menaklukkan samudera raya yang menyelubungi bumi (bnd. Kej 1:2, 9-10). Hardik murka Tuhan (ay.7) membuat air samudera ini lari kebingungan ke tempat yang telah dipersiapkan baginya (8). Penciptaan dilukiskan dengan penaklukan dan pengaturan Tuhan terhadap kekacauan samudera. ${ }^{59} \mathrm{Hal}$ ini merupakan penegasan berulang-ulang terhadap kepercayaan dan sastra Timur Dekat kuno yang memandang samudera sebagai kekuatan yang menakutkan, mereka sangat mencintai tanah tetapi gentar menghadapi lautan. ${ }^{60}$ Laut disebutkan kekuatan yang dapat merusak kehidupan. Allah telah menjinakkan kekuatan yang mereka anggap menakutkan tersebut. Karena itu pemisahan air

58 John R.W. Stott, Favorite Psalms (Chicago: Moody Press, 1988), 98.

${ }^{59}$ Keil and F.Delitzsch, Commentary on the Old Testament in Ten Volumes (Vol. VIII).

${ }^{60}$ James Montgomery Boice, Psalms: Volume 2 (Michigan: Grand Rapids, 2009), 841. Bahkan pandangan yang paling tradisional mengatakan bahwa ketidakmampuan ilah bangsabangsa untuk melakukan sesuatu terhadap kekuatan-kekuatan ini disebabkan karena bukan mereka yang menciptakan (mengaturnya) sejak permulaan bumi (bnd. Mzm 96:4-5). 
dan daratan, selain mengungkapkan keteraturan posisi daratan yang terpisah dari lautan, juga menyatakan keterjaminan hidup dari bahaya atau malapetaka. ${ }^{61}$

Selanjutnya mengatur sumber-sumber air sebagai pemelihara kehidupan (10-12), menciptakan tatanan tempat tinggal bagi masing-masing tumbuhan dan hewan sebagai lingkungan hidup mereka (13-18). ${ }^{62}$ Bait ini memuji Tuhan sebagai pemberi hidup. Air samudera raya yang telah ditaklukkan itu sekarang menjadi diatur dengan bijaksana menjadi sumber hidup untuk segala yang hidup di bumi. Walaupun ay.16-18 tidak mengandung pembicaraan langsung dengan Tuhan namun pemazmur merenung dan mengingat pegunungan Libanon yang megah dan kemegahan itu adalah hasil perbuatan Tuhan (13).

Ay.19-23, Allah menentukan/ mengordinasikan siklus kehidupan ciptaanciptaan tersebut dengan waktu yang telah Allah tetapkan (siang dan malam). Tuhan pengatur tatanan waktu dan yang ditentukan untuk menjadi pembagi waktu ialah bulan dan matahari (19). Bulan disebut lebih dahulu karena waktu dihitung mulai tampaknya bulan sampai hilangnya kembali (bnd. Yes 60:20). ${ }^{63}$ Ay.24-26, merupakan sebuah kesaksian atas hikmat Allah yang telah mengaturkan segalanya bahkan lautan yang luas dan lewiatan dapat dijinakkan dengan kuasa-Nya. Tuhan mahabijak yang menciptakan dengan kebijaksanaan (bnd. Ams 3:19; Yer 10:12). Apa yang dipikirkan pemazmur? Kesempurnaan dan keharmonisan segala sesuatu yang dilihatnya sebagai buah dari penciptaan Tuhan. ${ }^{64}$ Demikian lewiatan dan ular naga berkepala tujuh yang mendiami samudera raya tidak membahayakan lagi. Lewiatan adalah personifikasi jenis makhluk yang hidup dan memunculkan chaos. Lewiatan adalah sejenis monster laut yang besar yang turut membantu bila Ball sedang berperang (bnd. Yes 27:1), dan sering sekali disebutkan sebagai lawan dari Yahweh dalam berbagai pertempuran (bnd. Mzm 73:13-14; 89:10-11). Allah yang mengalahkan lewiatan di masa lalu, membuatnya menjadi tidak lagi menakutkan. ${ }^{65}$

\footnotetext{
${ }^{61}$ Pola pemisahan yang terdapat pada ayat-ayat ini senada dengan pola penciptaan yang terdapat pada Kej 1:4-10; Ay 38:8-11; Ams 8:27-31. Sinulingga, Tafsiran Alkitab: Kitab Amsal $1-9$.

${ }^{62}$ Prinsip universal yang mendasar dalam sastra-sastra hikmat adalah bahwa secara fisik dan moral alam semesta bekerja dengan teratur, semenjak ia diciptakan dengan hikmat Allah, dan berjalan dalam tatanan hukum sebab-akibat.

${ }^{63}$ Marie Claire Barth and B.A. Pareira, Tafsiran Alkitab: Kitab Mazmur 73-150 (Jakarta: BPK Gunung Mulia, 2015), 257.

${ }^{64}$ Boice, Psalms: Volume 2.

${ }^{65}$ Bahkan mitos ini juga ada bagi bangsa-bangsa timur lainnya, seperti naga yang menjadi musuh bulan dan matahari dalam mitologi China, atau sejajar juga dengan rahu dalam cerita keagamaan Hindu. Dalam kebiasaan mereka pada tahun baru semua orang menabuh genderang
} 
Ay.27-30 adalah ungkapan akhir terhadap gambaran kekuasaan Allah yang permanen terhadap segala kehidupan makhluk ciptaan-Nya. Pemazmur telah menyanyikan perbuatan-perbuatan Tuhan di langit, darat, dan lautan. Kebesaran dan kebijaksanaan Tuhan dalam penciptaan yang tak terpahami itu akhirnya memerlihatkan kebenaran ini bahwa "semuanya menantikan Tuhan supaya diberikan makanan pada waktunya" (27). Kesejahteraan segala sesuatu tergantung kepada kebijaksaan Tuhan semesta alam. Leupold dalam hal ini mengatakan bahwa teologi penciptaan yang seperti ini sangat berguna bagi masyarakat agraris, yang selalu diingatkan untuk berbakti kepada Allah yang telah menciptakan keteraturan alam, musim dan memberikan kesejahteraan bagi mereka, lalu mengembalikan sebagian pemberian tersebut sebagai rasa syukur bagi Sang Pencipta. ${ }^{66}$ Namun bukan hanya kesejahteraan segala sesuatu itu bergantung pada Tuhan, melainkan pula hidup dan mati dari segala makhluk ciptaan. Pemazmur lebih dahulu berbicara tentang hal kematian atau "kembali menjadi debu" (29) karena kata terakhir Tuhan adalah hidup (30). Apabila Tuhan mengambil hidup yang satu, Dia mau menciptakan hidup baru bagi yang lain. Demikian Tuhan terus-menerus "memerbaharui ciptaan" dengan kehidupan yang baru. ${ }^{67}$

Dan akhirnya ay.31-35 merupakan penutup himme (Abgesang) sebagai kesimpulan dari mazmur tersebut. ${ }^{68}$ Nyanyian pemazmur atas kebesaran dan kebijaksanaan Tuhan dalam karya penciptaan haruslah diteruskan sampai kepada akhir zaman. Oleh karenanya pemazmur berdoa dan berharap agar Tuhan tetap menyatakan kemuliaan-Nya dan bersukacita atas ciptaan-Nya (ay. 31; bnd. Kej 1:31). ${ }^{69}$

Apakah yang dapat disimpulkan dari mazmur ini? Mzm 104 ini adalah suatu madah kepada kebesaran, kebijaksanaan, kebaikan dan kemuliaan Tuhan dalam seluruh karya ciptaan-Nya. Mengundang pembaca menatap semesta alam dengan sikap hormat kepada Allah karena seluruh alam raya ini adalah ciptaan Tuhan. Teologi penciptaan dalam pasal ini mengetengahkan beberapa

atau bunyi-bunyian untuk mencegah naga agar pergi dan tidak melahap (cahaya) matahari atau bulan, mereka berdoa, sampai naga tersebut mengabulkan permintaan mereka. Lihat Keil and F.Delitzsch, Commentary on the Old Testament in Ten Volumes (Vol. VIII).

${ }^{66}$ H.C. Leupold, Exposition of the Psalms (Michigan: Grand Rapids, 1960), 730.

${ }^{67}$ Barth and Pareira, Tafsiran Alkitab: Kitab Mazmur 73-150.

${ }^{68}$ H.J. Krauss, Die Psalmen (Neukirchen-Vluyn: Neukirchener, 1960), 708-710.

${ }^{69}$ Pemazmur mengembangkan pengertian 7 hari dalam Kejadian 1 sebagai pekerjaan penciptaan yang dilakukan terus-menerus bagi kelangsungan ciptaan. Keil and F.Delitzsch, Commentary on the Old Testament in Ten Volumes (Vol. VIII). 
pernyataan tentang kebesaran, kebijaksanaan dan kebaikan Tuhan dalam karya ciptaan-Nya harus membuat kita berpikir. Dia telah mengubah dan mengaturkan segala kekuatan yang menakutkan menjadi sumber hidup bagi seluruh ciptaanNya. Seluruh ciptaan ini bergantung pada Tuhan dan semua saling bergantung supaya dapat berkembang sejahtera dan bertahan hidup. Segalanya diciptakan oleh Tuhan dengan hikmat-Nya untuk sebuah tatanan keharmonisan dan keteraturan.

\section{Implikasi}

Hikmat menjadikan Manusia sebagai Sahabat Alam. Beberapa sarjana menyarankan bahwa sastra hikmat awal Israel adalah bersifat sekuler, artinya tidak berkaitan dengan Allah. Tetapi agaknya pandangan itu tidak begitu berdasar karena di Israel kuno pemikiran "sekuler" itu hampir tidak mungkin ada. Apa yang dipikirkan dan dilahirkan oleh pengajaran hikmat Israel selalu berkaitan dengan bagaimana tatanan dunia yang harmonis sesuai dengan apa yang dikehendaki Yahweh. Lebih khusus lagi, secara luas diakui bahwa teologi hikmat adalah "teologi penciptaan" yaitu refleksi iman atas dunia yang dimaksudkan oleh Sang Pencipta. Allah Pencipta bermaksud dunia harus utuh, aman, makmur, damai, adil, berbuah, dan produktif, yaitu bahwa dunia harus ditandai di setiap bagian oleh syalom. Dengan cara yang sama, Allah Pencipta telah menetapkan batas-batas dan membangun imbalan dan hukuman ciptaan yang ditimbulkan dan digerakkan oleh tindakan yang bijak atau bodoh. Tindakan itu harus dilihat dalam jangka waktu yang panjang dengan memelajari banyak "kasus", untuk memerhatikan tindakan apa yang menghasilkan kesejahteraan dan tindakan apa yang menghasilkan masalah. Premis dari semua pengamatan dan generalisasi semacam itu adalah bahwa kehidupan dan kesejahteraan adalah ciptaan Tuhan. Allah pencipta berkehendak bahwa semua bagian dari ciptaan terkait satu sama lain, dan karenanya setiap keputusan dan setiap tindakan penting mendatangkan kesejahteraan keseluruhan, bukan parsial.

Eichrodt berpendapat bahwa titik pangkal dari tema penciptaan dalam PL bahwa penciptaan tersebut tidaklah untuk menggambarkan begitu saja bagaimana Allah yang bekerja secara nyata dan manual dalam proses pembentukan dunia, tetapi lebih dari itu adalah untuk meletakkan dan memerhadapkan Tuhan dalam porsinya sebagai Sang Penguasa alam semesta. Ide dasar dari penciptaan tersebut adalah menceritakan dengan bentuk mitologi 
tentang pertentangan yang diakibatkan oleh chaos. ${ }^{70}$ Yahweh adalah tokoh utama dan memiliki kekuatan yang unik sangat dasyat, dan sama sekali tidak ditemukan adanya kekuatan yang dapat menandingi kekuatan dan kuasa yang ada pada-Nya. Pandangan yang seperti ini disinyalir berangkat dari pola yang sama seperti dalam perjalanan pada saat mereka menjadi umat perjanjian Yahweh, Yahweh adalah sebagai kekuatan ilahi yang tunggal yang tidak dapat tertandingi oleh apa dan siapapun. Sehingga ketika mereka mencoba untuk "memandang ke belakang" (mencari tahu keberadaan mereka) melihat kepada masa penciptaan, maka segala sesuatu yang diciptakan adalah berada di bawah otoritas kekuasaan Yahweh. Hal itulah yang akan membantu manusia untuk dapat melihat dan mengerti karya-karya Tuhan yang kudus dan berkelanjutan sampai kekekalan.

Telah terlalu lama eksploitasi alam demi keuntungan manusia berlangsung dan merusak segalanya tanpa memikirkan secara mendalam efek keberlanjutan ciptaan. Manusia begitu "brutal" sehingga merusak segalanya. Argumentasi Borrong menarik, pengerusakan "eksternal" (alam, lingkungan hidup) ini disebabkan oleh kerusakan "internal" dalam diri manusia. ${ }^{71}$ Oleh karena itu perlulah lebih dulu manusia mengerti posisinya di hadapan Tuhan Sang Pencipta supaya mampu "mendamaikan" (mengkonsolidasi) dirinya yang rusak itu lalu mengerti apa yang menjadi tanggung jawabnya terhadap alam ketika ia ditempatkan di dunia ini.

Teks-teks penciptaan Sastra Hikmat yang telah dibicarakan tadi memberikan gambaran yang lebih utuh tentang tanggung jawab umat Allah terhadap alam ini. Manusia dan alam saling berhadapan sebagai subyek dengan subyek. ${ }^{72}$ Hikmat yang telah ada sejak mulanya dan bersama-sama dengan Allah menciptakan keteraturan demi kesejahteraan penghuni bumi, hikmat itu pulalah yang mendorong manusia untuk bertindak bijaksana serta bergandengan tangan dengan alam untuk kehidupan bersama yang syalom. Kerusakan salah satu sendi di alam ini jelas merupakan kerugian bukan hanya bagi alam tersebut, akibatnya juga berdampak bagi manusia. Meracuni alam itu berarti meracuni kehidupan bersama. Sehingga tidak ada jalan lain kecuali memosisikan diri untuk menjadi sahabat bagi alam ini, menyederajatkan diri dengan alam sebagai sesama ciptaan

${ }^{70}$ Walter Eichrodt, "In the Beginning: A Contribution to the Interpretation of the First Word of the Bible," in Creation in the Old Testament, ed. Benhard W Anderson (Philadelphia: Fortress Press, 2012), 67.

${ }^{71}$ Robert P. Borrong, Etika Bumi Baru (Jakarta: BPK Gunung Mulia, 2012), 38-39.

${ }^{72}$ Jonsen Sembiring, "Agama-Agama Sebagai Sahabat Alam," Jurnal Teologi Anugerah 3, no. 2 (2012): 79. 
yang harus saling menjaga dan hikmat memampukan manusia menjalankan tugas tersebut. Menghormati Allah Pencipta dengan bersahabat dengan alam ciptaan-Nya.

Norma keteraturan alam yang telah diciptakan Allah dengan hikmat adalah prinsip kehamonisan hubungan di antara unsur-unsur yang ada di dalamnya. Kekacauan (chaos) dan kuasa yang berpotensi untuk merusak keteraturan itu telah ditaklukkan Allah pada masa penciptaan. Dengan demikian tidak ada tempat di bumi ini bagi manusia yang menjadikan dirinya sebagai bagian dari chaos itu lagi. Chaos yang dimaksud dapat berbentuk keserakahan, komersialisme, hedonisme, eksploitasi tanah dan alam atas nama nilai ekonomi, eskalasi mekanis dengan polutannya, dan seterusnya. Hubungan yang harus setara itu berubah menjadi bentuk hirarkis yang menjadikan alam sebagai obyek kepuasan manusia.Chaos yang terjadi sering disebabkan oleh aktivitas manusia yang melampaui batas alam. ${ }^{73}$

Manusia diikutsertakan dalam pemeliharaan dan meneruskan penciptaan dalam kapasitasnya sebagai co-creator, ia bertugas untuk membawa seluruh penciptaan kepada langkah selanjutnya dalam proses menuju kesempurnaan. ${ }^{74}$ Pola hidup yang bersahabat dengan alam sebenarnya bukan hanya berguna bagi manusia semata, tetapi hal tersebut sebagai pujian terbaik bagi Sang Pencipta, memberikan keadilan kepada alam sebagai sesama ciptaan dan sekaligus sebagai perwujudan tujuan awal penciptaan yaitu keteraturan dan keterjaminan keberlangsungan. Kesadaran yang penuh dari manusia bahwa pemeliharaan harmonisasi diri dengan alam sebagai bentuk pujian terhadap Tuhan yang disembah akan berefek baik bagi lestarinya ekologi. Sehingga dengan demikian alam bukan lagi obyek, tetapi ia adalah ruang yang dianugerahkan kepada manusia untuk mempersembahkan pujiannya terhadap Sang Pencipta.

\section{Simpulan}

Mengimani Allah Trinitas artinya bukan hanya menjadikan penebusan dan pemeliharaan sebagai karya utama Allah, tetapi harus menempatkan karya penciptaan dalam proporsi iman yang setara. Tema penciptaan dalam Perjanjian Lama tidak hanya terdapat dalam kitab-kitab awal Perjanjian Lama tetapi juga terdapat pada bagian lain khususnya dalam Sastra Hikmat. Tidak ada bagian

\footnotetext{
${ }^{73}$ Drummond, Teologi \& Ekologi.

${ }^{74}$ Roy Charly Sipahutar, "Kajian Ekoteologis Tentang Konsep Tanah Dalam Perjanjian Lama Dan Implikasinya Bagi Pemeliharaan Tanah," BIA': Jurnal Teologi dan Pendidikan Kristen Kontekstual 2, no. 2 (2019): 173-174.
} 
kitab suci yang lain yang lebih banyak membicarakan tema penciptaan. Hikmat telah ada semenjak penciptaan, Allah dengan hikmat mengalahkan kekacauan dan memberikan keteraturan sebagai dasar hubungan makhluk ciptaan. Tidak ada dominasi di dalamnya. Keteraturan adalah nafas bersama untuk menjamin kesejahteraan nyata di bumi. Manusia diberikan tanggung jawab untuk menjamin keberlangsungan ciptaan dan hikmat memampukannya untuk dapat melaksanakan tugas mulia tersebut.

\section{Daftar Pustaka}

Allen, Leslie C. Word Biblical Commentary Volume 21: Psalms 101-150. Waco: Word Press, 1983.

Barth-Frommel, Marie-Claire. Ayub: Bergumul Dengan Penderitaan, Bergumul Dengan Allah. Jakarta: BPK Gunung Mulia, 2016.

Barth, Marie Claire, and B.A. Pareira. Tafsiran Alkitab: Kitab Mazmur 73-150. Jakarta: BPK Gunung Mulia, 2015.

Boice, James Montgomery. Psalms: Volume 2. Michigan: Grand Rapids, 2009.

Borrong, Robert P. Etika Bumi Baru. Jakarta: BPK Gunung Mulia, 2012.

Bullock, C. Hassel. An Introduction to the Old Testament Poetic Books. Chicago: Moody Press, 1988.

Childs, Brevard S. Introduction to the Old Testament as Scripture. Philadelphia: Fortress Press, 1980.

- Old Testament Theology in Canonical Context. Philadelphia: Fortress Press, 1985.

Christoph Barth. Theologia Perjanjian Lama 1. Jakarta: BPK Gunung Mulia, 2017.

Clines, David J.A. World Biblical Commentary Vo. 17. Nashville: Thomas Nelson, 1989.

Combs, A.E. The Creation Motifs in the Old Testament. Colombia: Colombia University Press, 1970.

Davidson, Andrew Bruce. A Commentary, Grammatical and Exegetical, on the Book of Job. Edinburgh: Biblio Life, 2011.

Dick, Michael B. "The Neo-Assyrian Royal Lion Hunt and Yahweh's Answer to Job." Journal Biblical Literature 125/2 (2006): 243-270.

Driver, G.R. The Psalms in the Light of Babylonia Research. Michigan: Grand Rapids, 1990.

Drummond, Celia-Deane. Teologi \& Ekologi. Jakarta: BPK Gunung Mulia, 2011. 
Eichrodt, Walter. "In the Beginning: A Contribution to the Interpretation of the First Word of the Bible." In Creation in the Old Testament, edited by

Benhard W Anderson. Philadelphia: Fortress Press, 2012.

Eissfeld, Otto. The Old Testament. Oxford: Basil Blackwell, 1966.

Feinberg, John. "God Ordains All Things." In Predestination and Free Will:

Four Views of Divine Sovereignty and Human Freedom, edited by David

Basinger and Randall Basinger. Downers Grove: Inter-Varsity Press, 2006.

Forrest, Robert William Edward. The Creation Motif in the Book of Job. New

York: The World Publishing Company, 1975.

Habel, Norman C. The Book of Job. London: SCM Press Ltd, 1985.

- The Earth Story in Wisdom Tradition. Sheffield: Sheffield Academi Press, 2001.

Harefa, Juliman. "Makna Allah Pencipta Manusia Dan Problematika Arti Kata

'Kita' Di Dalam Kejadian 1:26-27." Epigraphe: Jurnal Teologi dan Pelayanan Kristiani 3, no. 2 (2019): 107.

Hartley, John E. The Book of Job. Michigan: Grand Rapids, 1988.

Hermisson, Hans-Jurgen. "Observations on the Creation Theology in Wisdom."

In Creation in the Old Testament, edited by Bernhard W. Anderson, 119.

Philadelphia: Fortress Press, 1984.

J.H.Eaton. Job. London: T and T Clark, 1992.

Keil, C.F., and F.Delitzsch. Commentary on the Old Testament in Ten Volumes (Vol. VIII). Michigan: Grand Rapids, n.d.

Keller, James. "Process Theism and Theodicies for Problems of Evil." In The Blackwell Companion to the Problem of Evil, edited by Daniel HowardSnyder and Justin P. McBrayer. Oxford: Wiley Blackwell, 2013.

Kraeling, Emil G. The Old Testament Since the Reformation. New York: Schocken Books, 1969.

Krauss, H.J. Die Psalmen. Neukirchen-Vluyn: Neukirchener, 1960.

Leupold, H.C. Exposition of the Psalms. Michigan: Grand Rapids, 1960.

Luc, Alex. "Storm and the Message of Job." Journal for Study of the Old Testament 1 (2000): 111.

Lumbantobing, Sahat Martua. "Alam Dan Manusia: Vis a Vis.” Jurnal Teologi Anugerah 3, no. 2 (2012): 54-63.

Morris, Henry. Biblical Creationism. Michigan: Grand Rapids, 1993.

Murphy, R. A Consideration of the Classification Wisdom Psalms. Bonn: Congress Volume, 1963.

Panjaitan, Firman, and Hendro H. Siburian. "Allah Yang Kreatif Dan Dinamis 
Dalam Ayub 42: 7-17: Sebuah Perlawanan Terhadap Teologi Retribusi." Kurios: Jurnal Teologi dan Pendidikan Agama Kristen 6, no. 2 (2020): 240-254.

Rad, Gerhard von. Old Testament Theology Vol 1: The Theology of Israel's Historical Traditions. Norwich: SCM Press Ltd, 1975.

Rodd, C.S. The Book of Job. London: Epworth Press, 1990.

Sembiring, Jonsen. "Agama-Agama Sebagai Sahabat Alam.” Jurnal Teologi Anugerah 3, no. 2 (2012): 64-80.

Siahaan, Harls Evan Rianto. "Hikmat Sebagai Implikasi Pendidikan Kristiani: Refleksi 1 Raja-Raja 3:1-15." Dunamis: Jurnal Penelitian Teologi dan Pendidikan Kristiani 1, no. 1 (2016): 15.

Sihombing, Bernike. "Studi Penciptaan Menurut Kitab Kejadian 1:1-31.” Kurios 1, no. 1 (2018): 76.

Sin, Sia Kok, Mazmur Pujian, Mazmur Keluhan, Mazmur Ucapan Syukur, Analisa Bentuk, Mazmur Pujian, Mazmur Keluhan, and Mazmur Ucapan Syukur. "Mengalami Allah Melalui Kitab Mazmur 1." Aletheia 18, no. April 2016 (2016): 18-19.

Singgih, E. Gerrit. Hidup Di Bawah Bayang-Bayang Maut: Sebuah Tafsir Kitab Pengkhotbah. Jakarta: BPK Gunung Mulia, 2011.

Sinulingga, Risnawaty. Tafsiran Alkitab: Kitab Amsal 1-9. Jakarta: BPK Gunung Mulia, 2015.

Sipahutar, Roy Charly. "Kajian Ekoteologis Tentang Konsep Tanah Dalam Perjanjian Lama Dan Implikasinya Bagi Pemeliharaan Tanah.” BIA': Jurnal Teologi dan Pendidikan Kristen Kontekstual 2, no. 2 (2019): 166178.

Sipahutar, Roy Charly HP. "Revitalisasi Kekudusan Dalam Hidup Pelayan Kristen." Cultivation 476-482 (2018).

Sitanggang, Asigor Parongna. "Pengaruh Kosmologi Bumi Datar Dalam Eskatologi Alkitab." Bia': Jurnal Teologi dan Pendidikan Kristen Kontekstual 3, no. 1 (2020): 91-101.

Stott, John R.W. Favorite Psalms. Chicago: Moody Press, 1988.

Tampasigi, Ril, and Peniel C.D. Maiaweng. "Tinjauan Teologis Tentang Takut Akan Tuhan Berdasarkan Kitab Amsal Dan Implementasinya Dalam Hidup Kekristenan.” Jurnal Jaffray 10, no. 1 (2012): 118.

Terrien, S.L. The Book of Job: Introduction and Exegetis. Nashville: Abingdon Press, 1954.

Timmer, Daniel. "God's Speeches and Job's Responses." The Chatolic Biblical 
Penciptaan dalam Sastra... (Roy C.H.P. Sipahutar)

Quarterly 7 (2009): 286-305.

Vriezen, Th. C. Agama Israel Kuno. Jakarta: BPK Gunung Mulia, 2012.

Walton, John H. Ancient Israelite Literature in Its Cultural Context: A Survey of Parallels Psalms. Michigan: Grand Rapids, 1989.

Westermann, Claus. "Biblical Reflection on Creator-Creation." In Creation in the Old Testament, edited by Benhard W. Anderson, 93. Philadelphia: Fortress Press, 2012.

Westermann, Clauss. Elements of Old Testament Theology. Atlanta: John Knox, 1982.

Zimmerli, W. Old Testament Theology in Outline. Atlanta: John Knox, 1978.

- Ort Und Grenze Der Weisheit Im Rahmen Der Alttestamentlichen Theologie. Munich: Kaiser, 1963. 